\title{
Comparative studies on lentic environment of Mai pokhari, Ilam and Kechana jheel wetland ecosystems, Jhapa, Nepal (With reference to bottom dwelling fauna)
}

\author{
Kalu Ram Khambu Rai \\ Department of Zoolozy, Mechi Campus, Tribhuvan University, Bhadrapur- 5, Jhapa \\ E-mail:drraikr@ntc.net.np
}

\begin{abstract}
Mai Pokahri is a mountain lake situated in midland at an altitude of $2150 \mathrm{~m}$ from sea level whereas Kechana jheel is situated in lowland (Tarai) at an altitude of $63 \mathrm{~m}$ from the sea level respectively. The lentic environments of the both lakes vary in the composition of bottomdwelling fauna and limnetic fauna respectively. The comparative studies were carried out in two different years by sampling the macroinvertebrates periodically. The bottom-fauna at Mai pokhari was found higher than Kechana jheel. Mai pokhari is still in natural condition but Kechana jheel is losing its native entity because of aquaculture. Mainly, the abundance of Chironomids showed the stratification in Mai pokhari but abundance of Trichoptera and Coleoptera in Kechana jheel indicate unstable bottom condition because continuous application of manure for pre-conditioning it as a fish pond.
\end{abstract}

Key words: Lentic-environments, macro-invertebrates, stratification, biodiversity, conservation, Mai pokhari-Kechana jheel.

\section{Introduction}

Lentic environment includes lakes, ponds and wetlands. For the study of macroinvertebrates from such environments, two lakes were selected from East Nepal.

Ilam is a very beautiful hilly district having several scenic places. The major lentic habitat of this district is a hilltop crater formed natural lake, called Mai pokhari (Fig. 1) $\left(87^{\circ} 0{ }^{\prime} 25.7^{\prime \prime} \mathrm{N}-87^{\circ} 55^{\prime} 55.3^{\prime \prime} \mathrm{E}\right)$ It is situated at an altitude of $2150 \mathrm{~m}$ from the sea level, lies $15 \mathrm{~km}$ away from Ilam Bazaar to the north side. The volume of the water of the lake is 1.8 hectares and its depth varies from 2 to $5 \mathrm{~m}$ respectively. Its shape is irregular, having 9 corners surrounded by two community forests. It has an area of 80 hectares i.e., Bhedichowk Community Forest to the west and Deorali Community Forest to the east respectively (Fig. 1). Likewise, Jhapa district is situated at lowland from the southern side of eastern Siwalik range of east Nepal. It was covered with dense Sal forests 40 years ago, and rich in several important wetlands called Holi. Holis are natural depression with permanent water bodies formed nice lentic environments. But such environments of Jhapa district have been changed into cultivated land for paddy and tea productions and remained only a few remnants of forests with a few natural lakes and ponds. Among them Kechana jheel (Fig. 2) is the biggest lake which is situated at $63 \mathrm{~m}$ from the sea level. It is called the lowest part of Nepal as compared to Mt. Everest, the highest peak in the World. It occupies an area of 7 hectares. It has been utilized as a fish production pond which is deteriorating its natural entity. In these ponds sampling of macro-invertebrates (zooplanktons and 
nektons) were taken by means of Petersen's grab. Mainly Chironomids, Oligochaetes, Polychaetes and other zoo-benthos were collected to show the comparative distribution and abundance in those ponds. Such studies help to classify the lakes and form the bases to predict the situation of the lentic environments for conservation of biodiversity.

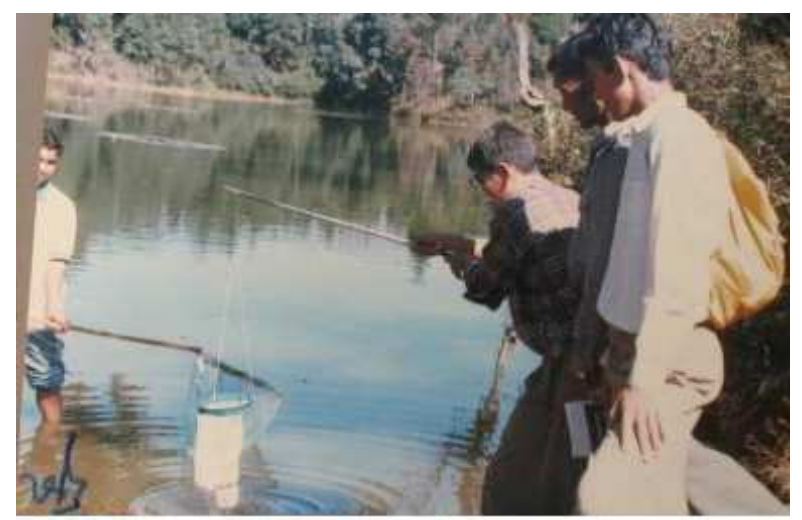

Figure 1. Mai pokhari lake: collecting samples on southern gate, using samplers.

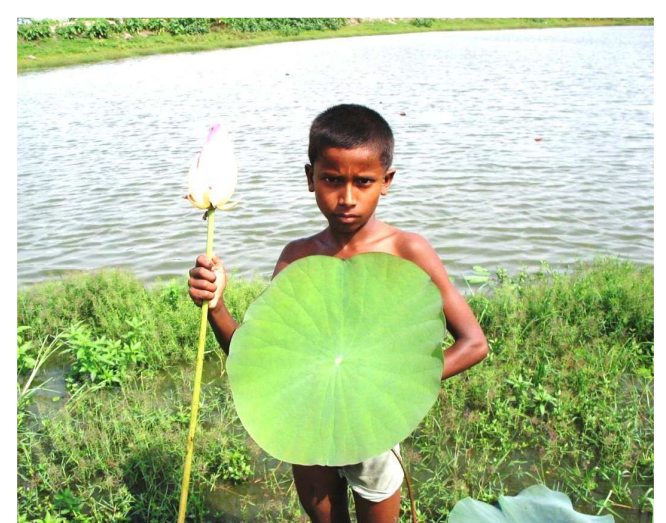

Figure 2. Kechana jheel: a manipulated natural lake in Jhapa district, showing a local boy with native flower (Nelumbo nucifera).

\section{Methodology}

During the sampling period, temperature was recorded and water samples collected were analysed by using titration methods (APHA, 1998). Random samplings were taken by using Peterson's grab having an area of $0.0289 \mathrm{~m}^{2}$. The sampling stations were fixed at 9 corners at Mai pokhari and collected bottom samples. Freshly collected samples from the bottom of the pond, were first poured down into an open bucket and stirred with a rod. Since the bottom silt taken with the organisms pass through a 28 mesh sieve, mixing the silt and water. This prevents injury to the soft-bodied midge larvae and pupae and other forms taken. Required amount of water was added to the bucket to dilute the bottom silt in order to pass it through the sieve. Then it was transferred to a jar by back pouring through the sieve and washing the material into a wide-mouth jar (Needham \& Needham, 1961). The macroscopic specimens of bottomdwelling fauna remained as residue on sieving 30 mesh sieve, were collected into a polythene bag and a tagging slip was put inside adding a drop of $10 \%$ formalin. In this way five samples were taken from each station. Like-wise Kechana jheel was also divided into 7 sections by earthen dams which were used each separate sampling station. Five samples were collected from each station, and the sorting out was done accordingly as mentioned at Mai pokhari survey. All the collected samples were brought to the Zoology Laboratory of Mechi Campus and sorting out of animals were accomplished. Then the macroscopic bottom-dwelling fauna were identified, using practical manual book (Needham \& Needham, 1961).

\section{Results}

By using physico-chemical parameters, dissolved oxygen, range of free $\mathrm{CO}_{2}$, hardness and acidity were calculated. The results are given in Table 1. 
During the sorting out of the samples, 688 specimens were recorded from Mai pokhari and 248 specimens were counted from the total sample sorted out from Kechana jheel which are enlisted in Table 2.

Table 1. Climatic data from Mai pokhari and Kechana jheel ecosystems.

\begin{tabular}{lcc}
\hline Parameters & Mai pokhari & Kechana jheel \\
\hline Altitude & $2050 \mathrm{~m}$ & $63 \mathrm{~m}$ \\
Temperature & & \\
\multicolumn{1}{c}{$\quad$ Air } & $18^{\circ} \mathrm{C}$ & $24^{\circ} \mathrm{C}$ \\
Water & $21^{\circ} \mathrm{C}$ & $22^{\circ} \mathrm{C}$ \\
pH range & $6(5.5)$ & 6 \\
Dissolved oxygen & $24 \%$ or $2.1 \mathrm{mg} / 1$. & $5.0 \mathrm{mg} / 1$ \\
Range of free $\mathrm{CO}_{2}$ & & $3.99 \mathrm{mg} / 1$ \\
Range of total hardness & & $32.4 \mathrm{mg} / 1$ \\
Acidity & & $20 \mathrm{mg} / 1$ \\
Permanent hardness & & $26 \mathrm{mg} / 1$ \\
Temporary hardness & & $6.4 \mathrm{mg} / \mathrm{l}$ \\
\hline
\end{tabular}

Table 2. Biodiversity of fauna from Mai pokhari and Kechana jheel.

\begin{tabular}{lcccccc}
\hline Name of lakes & \multicolumn{3}{c}{ Mai pokhari } & \multicolumn{3}{c}{ Kechana jheel } \\
\hline $\begin{array}{l}\text { Zoo-benthos } \\
\text { composition }\end{array}$ & Total no. & Abundance & $\%$ & Total no. & Abundance & $\%$ \\
\hline Chironomidae larvae & 449 & 199.5 & 62.9 & 18 & 17.8 & 7.3 \\
Hemiptera & 94 & 41.7 & 13.2 & - & - & - \\
Trichoptera & 55 & 24.4 & 7.4 & 187 & 184.8 & 75.4 \\
Tubificidae & 43 & 19.1 & 6.0 & 15 & 14.8 & 6.0 \\
Coleoptera & 17 & 7.5 & 2.3 & 21 & 20.7 & 8.5 \\
Ephemeroptera & 8 & 3.5 & 1.1 & 1 & 0.9 & 0.4 \\
Oligochaeta & 4 & 1.7 & 0.6 & - & - & - \\
Odonata & 7 & 3.1 & 0.9 & 1 & 0.9 & 0.4 \\
Plecoptera (Sandfly) & 8 & 3.5 & 1.1 & - & - & - \\
Collumbola & 2 & 0.8 & 0.3 & - & - & - \\
Crustacea (prawn) & - & - & - & 3 & 2.9 & 1.2 \\
Piscidae & - & - & - & 1 & 0.9 & 0.4 \\
Arachnidae & 1 & 0.4 & 0.1 & 1 & 0.9 & 0.4 \\
\hline
\end{tabular}

As per the results, Chironomids were found dominant at Mai pokhari whereas Trichoptera were dominant at Kechana jheel. Pisidae and Crustaceans from Mai pokhari and Hemiptera, Oligochaeta, Plecoptera, Collumbola, from Kechana jheel were not recorded. On the whole, 11 groups of macro-invertebrates from Mai pokhari and 9 groups of macro-invertebrates from Kechana jheel were identified so far.

\section{Discussion}

During the survey period, temperature recorded at Mai pokhari and Kechana jheel were $18^{\circ} \mathrm{C}$ and $24^{\circ} \mathrm{C}$ respectively (Table 1). Physico-chemical stratification has a profound effect upon both the quantitative and qualitative distribution of the bottomdwelling organisms during the changing of seasons.

According to the results of data analysis, the range of dissolved oxygen was found 2.1 $\mathrm{mg} / \mathrm{l}$ at Mai pokhari and $5.0 \mathrm{mg} / \mathrm{lit}$ at Kechana jheel (Table 1). According to Shelford (1911) over sandy bottoms of younger ponds, abundant DO $(6.56 \mathrm{mg} / \mathrm{l})$ prevails 
during the open season; water over vegetation has moderate DO at least during the day, and over bottom with vegetation removed has lowermost DO (3.34 cubic centimeter) during the spring months but during the summer are devoid of oxygen.

In general dissolved oxygen at a level of $3 \mathrm{mg} / \mathrm{l}$ or lower should be regarded as hazardous to lethal under average lake condition; and that $5 \mathrm{mg} / \mathrm{l}$ or more of dissolved oxygen should be present in waters, if conditions are to be favourable for fresh water fishes (Elliott, 1971). The above consequences showed that the hilly lake Mai pokhari contains less oxygen than Kechana jheel.

The range of $\mathrm{pH}$ was found 5.5 at Mai pokhari and 6 at Kechana jheel (Table 1). Wiesenberger-Lund (1930) reported a range of $\mathrm{pH} 4.4$ to 9.4 in ponds. In some ponds, the $\mathrm{pH}$ remains practically constant over considerable period of time. It is claimed that heavy rain may produce marked alterations in the $\mathrm{pH}$ of some ponds, especially those in which the buffer action is low. Due to evaporation of pond surface also accompanied by progressive changes; in $\mathrm{pH}$. Thus mountain lake Mai pokhari seemed more acidic than lowland lake Kechana jheel.

As per the results of macroscopic fauna found (688 individual macro-bottom-dwelling fauna) at Mai pokhari included Chironomids 65.26\%, Hemiptera 13.6\%, Trichoptera $7.9 \%$, Tubificidae $6.2 \%$, Coleoptera $2.4 \%$, Ephemerotera $1.1 \%$, Plecoptera $1.1 \%$, Odonata $0.9 \%$, Oligochaeta $0.6 \%$ and others $0.4 \%$ respectively. Likewise, the total data (248 individual macro-bottom-dwelling fauna) of Kechana jheel showed Chironomids 7.3\%, Trichoptera 75.4\%, Tubificidae 6.0\%, Coleoptera 8.5\%, Crustacea $1.2 \%$, Piscidae $0.4 \%$ and others $0.8 \%$ respectively. These results are compared to both lentic environments, situated vertically (north-south): Mai pokharai $(2150 \mathrm{~m})$ at high altitude and Kechana jheel at low altitude $(63 \mathrm{~m})$. Much attention has been given to bottom fauna since it lays a very important part in the nutrition cycles of the lentic environment is certain. Forms of basin, character of bottom and of bottom deposits, water movements, and other feature may be such as to militate against the development of a bottom fauna which would be a true index of the general richness of the pond (Welch, 1951). When a rich bottom-dwelling fauna is present high productivity is common, but not necessarily insured. Chironomidae larvae have hemoglobin which may act as a store house of oxygen, so seems reddish. On the other hand, the Tubificidae forms an apparently being the more resistant to the bottom environment.

\section{Conclusion}

With the help of above mentioned consequences, it can be concluded that Mai pokhari has minimal percentage of dissolved oxygen $(2.1 \mathrm{mg} / \mathrm{l})$ with rich in macroscopic bottom-dwelling fauna having high percentage of Chironomids $(65.2 \%)$, confirms to be a eutrophic lake. In this way, lowland lake Kechana jheel deserves higher percentage of dissolved oxygen $(5.0 \mathrm{mg} / \mathrm{l}$.) and very less number of macro-bottomdwelling fauna with minimal percentage of Chironomids $(7.3 \%)$ which helps to confirm that the lake to be an oligotrophic lake. Furthermore, Mai pokhari is still in natural condition with higher biodiversity whereas Kechana jheel has been utilized by village development committee (VDC) for fish production. So it is an urgent need to draw the attention of concerned authorities to stop any exploitation of these lakes to restore the natural ecosystems for future generations. 


\section{Acknowledgements}

I am grateful to my teachers Prof. Dr. U.K.R. Yadav (Central Department of Environmental Science, T.U.) for his incredible guidance. I would like to thank to Pro. Dr. Hermann Schleich and Dr. Christiane Anders for providing me literatures. I am thankful to Dr. B.R. Subba and Mr. K.P. Limbu for comments and publishing in the journal. Lastly, I thanks to Zoology Department of Mechi Campus for providing me lab facilities and also to Mr. Lokraj Pokharel who accompanied with me during field trips so far.

\section{References}

Elliott, J.M. 1971. Some methods for statistical analysis of samples of bottom-dwelling invertebrates. Sci. Publ. Freshw. Biol. Assoc. 25: 148.

Needham, J.G. \& P.R. Needham. 1961. A guide to the study of fresh-water Biology. $5^{\text {th }}$ ed., Holden-Day, INC., San Francisco. pp. 17-62.

Rai, K.R. 1983. Preliminary investigation on the Zoo-benthos in the shallower depths of lake Phewa in Pokhara valley, M.Sc. thesis, Central Department of Zoology, T.U.

Welch, P.S. 1951. Limnology. In: Zoological Sciences (Ed. E.J. Boell), McGraw-Hill Publications. pp. 315-381.

Yadav, U.K.R., M.J. Behan, P.K. Jha \& D.B. Zobel. 1987. A practical manual for Ecology. Ratna Book Distributors, Bag Bazaar, Kathmandu, Nepal. 47 p. 